\title{
音楽に含まれる言語情報が文章課題の遂行に及ぼす影響* 一日本語歌詞と韓国語歌詞による比較一
}

\section{1.はじめに}

主目的の作業を行う際，それとは別の事柄を平行して 行うことがある。この行動は「何かをしながらする作業」 より,「ながら作業」と呼ばれている。「ながら作業」は 平行して行う作業によって様々であるが，特に音楽を聴 きながら行う「ながら作業」について注目してみると， 知的作業を行う仕事場 ${ }^{1)}$ や学習時2)におけるBGMとして の利用が広く行われている。仕事場や学習時における BGMは, クラシック，ポップス，ジャズなど様々である が，特に本邦の大学生が日常の学習時に使用している BGMは言語音を含むものが多いと指摘されている ${ }^{3)}$.

先行研究4)では, 日本語を母国語とする日本人被験者 に対して，音楽に含まれる歌詞（言語情報）が文章課題 の遂行に与える影響を検討するために，歌詞を含む音楽， 歌詞を抜いた同じ音楽（音楽のみ），無音の3条件の環境 下で文章課題を行わせる比較実験を行った。その結果と して，歌詞を含む音楽を聴かせた場合において，音楽の み聴かせた場合や無音の場合よりも作業成績の低下が認 められた。人間は音楽に含まれる歌詞（言語情報）を知 覚し，聴覚から言語情報を含む音楽と，同時に視覚から 文章読解などの言語情報を処理する課題が与えられた場 合には, 聴覚と視覚の $2 つ の$ 経路からの言語情報を同時平 行処理する必要があるために, 作業成績が低下したもの と考察した。しかし，人間の音声は音楽よりも「不快さ」 が高いと言われて打り ${ }^{5}$ ，人間の音声そのものの影響であ るのか, 歌詞に含まれる言語情報の影響であるのかは明 らかにできなかった。 そのため, 母国語以外の歌詞を含

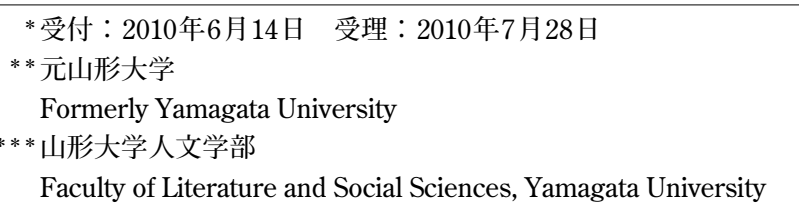

\section{門間政亮**, 本多 薫***}

む音楽を聴かせて，日本語の文章課題を行わせた場合に， 作業成績に影響を与えるか否かを確認する必要がある。 しかし，母国語以外の歌詞を含む音楽の心理的な影響を 検討した研究3) はあるが，作業成績について検討した研 究はみられない。

そこで本研究では，韓国語を習得しておらず，理解で きない被験者に対して，日本語の歌詞を含む音楽，同じ 歌手が歌った韓国語の歌詞を含む音楽，歌詞を抜いた同 じ音楽，無音の 4 つの環境下で日本語の文章課題を行わ せ，作業数，誤答率を評価指標とする比較実験を行い， 先行研究4) の再現性を確かめると共に，音楽に含まれる 言語情報の意味が理解できる場合と理解できない場合に おいて，文章課題の遂行に与える影響に違いがみられる のかについて検討する。

\section{2. 方 法}

\section{2-1. 被験者}

被験者は日本語を母国語とする日本人男子学生6名（年 齢は20～22歳）である. 実験前に視力，聴力および循環 機能が，過去打よび現在において正常であることを確認 した。また，授業等に打いて韓国語を学習しておらず， 韓国語を理解できないことを確認した。実験前日は午後 11時までに就寝するように指示した，実験当日は昼食を 午前11時に取ることとし，午後1時より実験を開始した。 なお，昼食後および実験中の飲食，喫煙を禁止した。

\section{2-2. 実験環境}

実験に用いる音楽環境は，日本語および韓国語が堪能 な女性歌手「BoA」を取り上げ，日本語の歌詞が入って いる音楽（以下，「日本語音楽」とする），韓国語の歌詞 が入っている同じ音楽（以下，「韓国語音楽」とする)， 
歌詞を抜いた同じ音楽（以下，「音楽のみ」とする）, 音 楽を暴露しない（以下，「無音」とする）の4条件とした。 提示した音楽は, 「BoA」の楽曲の中から, “ID ; Peace B”, "Milky Way", "Don't start now", "Someday, Somewhere" の4曲を選定し，曲間のインターバルは設けず，曲の終了 と同時に次の曲を再生した。 なお,「音楽のみ」は, 同じ $\mathrm{CD}$ に収録されているカラオケ用のものを使用した，音楽 環境について，テレビやラジオ等で流れた場合に聞く程 度で，普段聞き馴染みのない曲であることを被験者全員 に確認した．音源はデジタル録音されたものをパーソナ ルコンピュータで再生し, 被験者にヘッドホン (Victor HP-RX700）を装着させ，音楽を暴露した。但し，無音の 場合もへッドホンを装着させた。音量は騒音計（リオン NL-27）により，ヘッドホンのスピーカ部より $1 \mathrm{~cm}$ 離れ た位置で70 db（LAeq：15分間）に調整した。実験は静 かな個室で行い, 室内温度は $24^{\circ} \mathrm{C}$, 湿度 $37 \%$, 室内の暗 騒音は33.2 db（LAeq：1分間）であった。また，作業机 の表面照度は, JIS Z 9110による照度基準における, 文章 校正作業に適するとされる750～1500 1xに収めるため， 1300 lxに調整した。

\section{2-3. 実験内容}

実験は, 音楽環境の異なる4回 (日本語音楽, 韓国語音 楽, 音楽のみ, 無音) に, 最初に実験環境や課題に慣れさ せるためのダミー (無音) 1回を加え, 合計5回行った。 それぞれの音楽環境下で, 15分間の文章課題を行わせた。 なお，文章課題を行う前には，15分間の開眼安静をとっ た。実験はダミーを最初に行い，それ以降の「日本語音 楽」,「韓国語音楽」,「音楽のみ」,「無音」の順番を被験者 毎に変更した。文章課題は, 紙に印刷した新聞記事（社 説：毎日新聞）の文章中から動詞のみを抜き出し, 該当部 分に蛍光マーカーで線を引くという作業とした. 動詞は活 用のある自立語で述語になることができるほかに，修飾 語・接続語・独立語にもなる ${ }^{6)}$ ため, 動詞のある前後の文 章を読み意味を理解しないと的確に抜き出すことができな い、そのため，文章中から動詞を抜き出す作業とした。 ま た，採点基準を一定にするために，日本語形態素解析シス テム7を用いて模範解答を作成した。採点基準に定める動 詞部分に線が引かれていない場合を誤答とした。

\section{3. 実験結果}

\section{3-1. 作業数}

図1に4条件の音楽環境下での作業数の結果を示す。こ

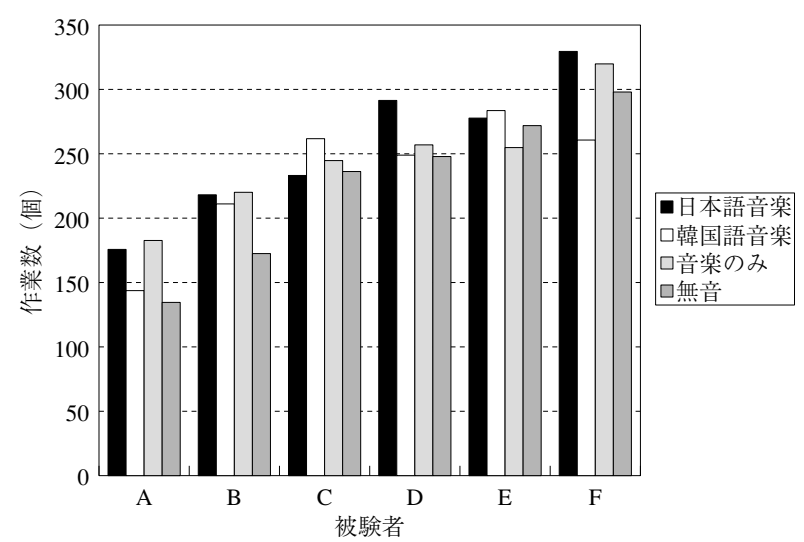

図1 音楽環境条件別の各被験者の作業数

Fig. 1 The number of tasks for each subject under different musical environments.

こで言う作業数とは, 各被験者において作業時間15分間 に到達した時点の採点基準に定める動詞の総数のことで ある. 図1より, 各被験者での「日本語音楽」,「韓国語音 楽」,「音楽のみ」,「無音」の作業数を比較すると差違は 見られるが，全被験者を見比べた場合特定の傾向はみら れない。このうち, 日本語音楽と韓国語音楽の音楽環境 下での作業数に注目すると, 日本語音楽と韓国語音楽の 音楽環境下での作業数に扔いても両者の間に特定の傾向 はみられない。次に各被験者の無音時に打ける作業数を 比較すると, 作業数が最も少ない被験者Aが 135 個, 最も 多い被験者Fが298個であり，2.21倍の差がぬられる。音 楽環境と被験者を要因とした二元配置の分散分析 ${ }^{8)}$ を行 つた結果, 被験者要因において有意な効果が認められた (被験者要因 $(\mathrm{F}(5,15)=28.37, \mathrm{p}<0.01))$ が, 音楽環境 要因では有意な効果は認められなかった（音楽環境要因 $(\mathrm{F}(3,15)=2.41)$.

\section{3-2. 誤答率}

図 2 に 4 条件の音楽環境下での誤答率の結果を示す。こ こで言う誤答率とは, 各被験者において作業時間15分間 での誤答の総数を作業数で割ったものとした（誤答率 $(\%)=($ 誤答の総数 $/$ 作業数 $) \times 100)$. 図 2 より, 各被験 者での「日本語音楽」,「韓国語音楽」,「音楽のみ」,「無 音」の誤答率を比較すると, 全ての被験者において「日 本語音楽」での誤答率が最も高い傾向が見られた。また， 日本語音楽と韓国語音楽の音楽環境下での誤答率を比較 すると, 被験者6名全員において, 韓国語音楽よりも日本 語音楽の音楽環境下での方が, 誤答率が高い傾向がみら れた，次に各被験者の無音時における誤答率を比較する

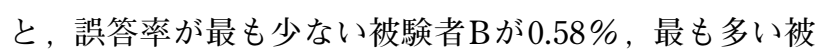




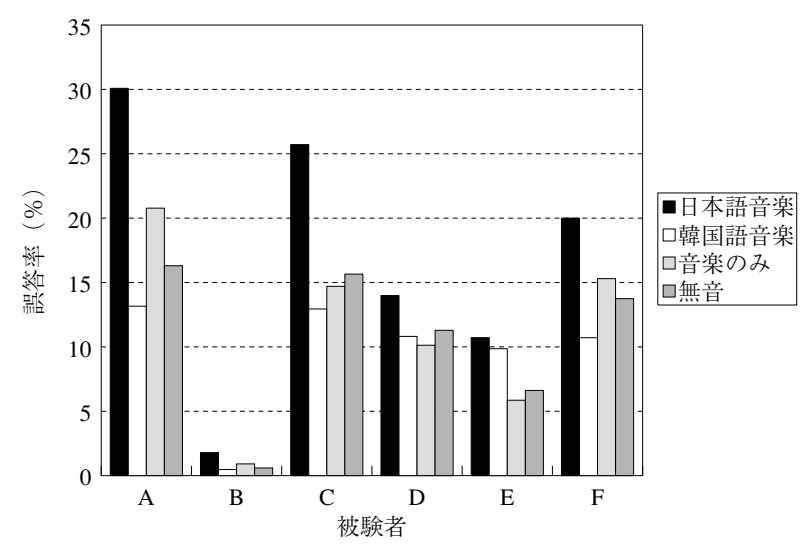

図2 音楽環境条件別の各被験者の誤答率

Fig. 2 Error rates for each subject under different musical environments.

表 1 多重比較の結果（誤答率）

Tab. 1 Results of multiple comparison (error rate).

\begin{tabular}{|c|c|c|c|c|}
\hline & 日本語音楽 & 韓国語音楽 & 音楽のみ & $\begin{array}{l}\text { 無音 } \\
\end{array}$ \\
\hline 日本語音楽 & & $7.41^{* *}$ & $5.81^{*}$ & $6.39 *$ \\
\hline 韓国語音楽 & & $\alpha$ & 1.60 & 1.02 \\
\hline 音楽のみ & & & 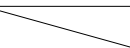 & 0.58 \\
\hline 無音 & & & & \\
\hline
\end{tabular}

験者Aが16.3\%であり，28.1倍の差がみられる．音楽環境 と被験者を要因とした二元配置の分散分析8) を行った結 果, それぞれの要因において有意な勃果が認められた (音楽環境要因 $(\mathrm{F}(3,15)=7.43, \mathrm{p}<0.01)$, 被験者要因 $(\mathrm{F}(5,15)=21.22, \mathrm{p}<0.01))$.

表1に音楽環境での多重比較（Tukey's method）の結果 を示す。表1より，「日本語音楽」と「韓国語音楽」,「日 本語音楽」と「音楽のみ」,「日本語音楽」と「無音」の 間に有意な効果が認められた。

\section{4. 考 察}

日本語音楽, 韓国語音楽, 音楽のみ, 無音の 4 つの環境 下で文章課題を行わせた。 その結果, 文章課題の作業数 には音楽環境間で差異がみられなかった。しかし, 日本 語音楽の音楽環境下において, 他の音楽環境下よりも誤 答率が増加した。このことは, 筆者らの先行研究4) と同 様の結果であった。本研究に打ける被験者数は 6 人である が, 作業数と誤答率が先行研究と同様の結果であったこ とから, 先行研究の再現性は十分に確かめることができ るものと考えられた.
本研究においては，日本語と韓国語による歌詞を同じ 歌手が歌ったものを取り上げ, 音声, 音圧レベル, 音楽 を同じに設定した。その結果，文章課題と同じ言語であ る「日本語音楽」の音楽環境下に打いて，「韓国語音楽」 の音楽環境下と比較して作業数には有意差は認められな かった，クラシック音楽，ホワイトノイズ，スピーチラ イクノイズ (日本語の音声), 無音の $4 つ の$ 音環境下で日 本語文章のタイプ入力作業を行わせた研究9)では, 音環 境の違いによって入力文字数は変化しないと報告されて いる．このことから，「日本語音楽」や「韓国語音楽」の 音楽環境下では, 作業数への影響は小さいと考えられる.

また，文章課題と同じ言語である「日本語音楽」の音 楽環境下に打いて,「韓国語音楽」の音楽環境下と比較し て誤答率が有意に増加した。脳活動を測定したこれまで の研究では, 日本語の言語処理過程では下前頭葉 (Broca 領域），後上側頭葉（Wernicke領域）といういわゆる言 語野において賦活化が認められる ${ }^{10)}$ ，人間は視聴覚情報 を大脳で同時並行处理している ${ }^{11)}$ ， と報告されている. また，感覚入力（聴覚または視覚）は意識にのぼる前に 自動的で無意識な処理を受ける ${ }^{12)}$ ，脳は注意を向けてい ない情報も意味的処理されてから選択フィルタを通して， 必要な情報を選択している ${ }^{13)}$ ，入力された情報への「注意」 は，意識的にも無意識的にも働かせることができる ${ }^{14)} と$ 考えられている。すなわち，歌詞に含まれる言語情報を 無意識的に処理し，歌詞の中に自分が興味のある言葉や 単語が出てきた場合には，注意を働かせていると推察さ れる。つまり，意味の理解できる日本語の歌詞について は，興味のある言葉や単語に注意を働かせてしまうため， 聴覚と視覚の $2 つ の$ 経路からの言語情報を脳の言語野 ${ }^{10)}$ において同時並行に処理しなければならなくなるが，意 味の理解できない韓国語の歌詞については，興味のある 言葉や単語に注意を働かせる必要がないため, 視覚の経 路からの言語情報のみを処理すればよいものと推察され る。このことは, 䛊答率に扔ける音楽環境での多重比較 の結果（表1）より，「韓国語音楽」と比較して，歌詞を 含まない「音楽のみ」や，「無音」との間に有意な効果が 認められなかったことからもうかがえる.

先に示した研究9)では，「いずれの音環境においても， タイプ作業効率の変化は, 入力文字数の変化ではなく, ミス入力文字数や誤答率のようなミスの増减として現れ る」と述べている。このことからも，歌詞（言語情報） を含む音楽の中でも，意味が理解できる言語情報を含む 音楽は, 文章課題を行う際の作業処理量への影響は小さ いが，作業成績を低下させると考えられる。 


\section{5. まとめ}

本研究では, 韓国語を理解できない被験者に対して, 日本語の歌詞を含む音楽, 韓国語の歌詞を含む同じ音楽, 歌詞を抜いた同じ音楽, 無音の4つの環境下で日本語の文 章課題を行わせ, 作業数, 䛊答率を評価指標とする比較 実験を行い, 先行研究4) の再現性を確かめると共に, 音 楽に含まれる言語情報の意味が理解できる場合と理解で きない場合において, 文書課題の遂行に与える影響に違 いがみられるのかについて検討した。 その結果, 作業数 と誤答率の結果は先行研究と同様の結果が得られ, 再現 性が確かめられた。また, 日本語の歌詞を含む音楽を聴 いた場合では，韓国語の歌詞を含む同じ音楽を聴いた場 合と比較して, 作業数は特定の傾向がみられないが, 誤 答率が増加することが認められた。韓国語の歌詞を含む 同じ音楽を聴いた場合の誤答率について，歌詞を抜いた 同じ音楽を聴いた場合, 及び無音の場合の䛊答率と比較 して差がみられなかった。これらのことから, 歌詞（言 語情報）を含む音楽の中でも, 意味が理解できる言語情 報を含む音楽では，文章課題における作業成績を低下さ せることを示した，そのため，学習する場合やオフィス において言語的な作業を行う場合には，意味が理解でき る歌詞などの言語情報を含む音楽を流しながら行うこと は望ましくないと思われる.

\section{参考文献}

1）人間生活工学研究センター編：人間生活工学第 4 卷快 適な生活環境設計, 61-69, 丸善, 東京, 2004.
2）中山実, 清水康敬：音環境が与える音読速度への影響と 瞳孔面積変化, 日本音響学会誌, 45 (5), 368-373, 1989.

3）志水佳和, 菅千索：計算課題の遂行に及ぼすBGMの影 響について (2), 和歌山大学教育学部教育実践総合センタ 一紀要, 14, 103-112, 2004.

4）門間政亮, 本多薰：音楽に含まれる言語情報が文章課 題に与える影響に関する検討, 人間工学, 45 (3), 170-172, 2009.

5）吉田拓正：鉄道騒音, 音楽, 音声の主観的評価と作業妨 害について, 日本建築学会大会学術講演梗概集, D, 145$146,1987$.

6） 三角洋一,相澤秀夫ほか：新編新しい国語1,190-193, 東 京書籍, 東京, 2008.

7）松本祐治：形態素解析システム「茶䈳」, 情報処理, 41 (11), 1208-1214, 2000.

8）市原清志：バイオサイエンスの統計学一正しく活用す るための実践理論一, 南江堂, 東京, 174-183, 1990.

9）岩城護, 新川慎吾, 木竜徹：タイプ作業における音環境 の生体影響と作業効率の変化, 電子情報通信学会技術研 究報告, MBE, MEとバイオサイバネティックス, 108 (52), 19-24, 2008.

10）佐々祐子, 杉浦元亮, 渡辺丈夫, 秋月祐子, 佐藤滋, 川島 隆太 : 言語処理とその脳の活動領域の考察, 信学技報, NLC2002-23, 91-97, 2002.

11）秋田剛, 平手小太郎, 安岡正人: 大脳に打ける視聴覚情 報の同時並行処理についてー誘発電位計測による視聴覚 情報の知覚に関する研究一, 日本建築学会大会学術講演 梗概集, D-1, 771-772, 1997.

12) D. A. Norman: Toward a theory of memory andattention, Psychological Review, 75(6), 522-536, 1968.

13）多鹿秀継, 川口潤, 池上知子, 山佑嗣 : 情報処理の心理学 (認知心理学入門), 36-166, サイエンス社, 東京, 1992.

14）大石晴美: 脳科学からの第二言語習得論, $8-28$, 昭和堂, 京都, 2006. 